Journal of Experimental and Clinical Medicine https://dergipark.org.tr/omujecm

Research Article

J Exp Clin Med

2021; 38(3): 294-300

doi: $10.52142 /$ omujecm. 38.3 .16

\title{
Antitumoral effects of Santolina chameacyparissus on non-small cell lung cancer cells
}

\author{
Yasemin SAYGIDEGER ${ }^{1,2, *}$, Burcu SAYGIDEĞER DEMİ ${ }^{3 \oplus}$, Tugba TASKIN TOK ${ }^{4,5}$, Alper AVCI ${ }^{6}$ Aycan SEZAN $^{3}$, \\ Oya BAYDAR ${ }^{1}$, Ezgi OZYILMAZ ${ }^{1}$ (i) \\ ${ }^{1}$ Department of Pulmonary, Cukurova University School of Medicine, Adana, Turkey \\ ${ }^{2}$ Department of Translational Medicine, Institute of Health Sciences, Cukurova University, Adana, Turkey \\ ${ }^{3}$ Department of Biotechnology, Graduate School of Science and Technology, Cukurova University, Adana, Turkey \\ ${ }^{4}$ Department of Chemistry, Faculty of Arts and Sciences, Gaziantep University, Gaziantep, Turkey \\ ${ }^{5}$ Department of Bioinformatics and Computational Biology, Institute of Health Sciences, Gaziantep University, Gaziantep, Turkey \\ ${ }^{6}$ Department of Thoracic Surgery, Cukurova University School of Medicine, Adana, Turkey
}

Received: 03.01.2021 • Accepted/Published Online: 02.02.2021 • Final Version: 23.04 .2021

\begin{abstract}
Santolina chameacyparissus (Santo) is an evergreen plant which is traditionally used for its anti-inflammatory effects in various diseases. In this study, we aimed to explore the effects of Santo in non-small cell lung cancer cells. We extracted volatile oil from the plant and evaluated cytotoxicity, apoptosis, and motility effects of the extract on two non-small cell lung cancer (NSCLC) cell lines; one is a patient derived and the other one is a commercially available A549 cells. We also identified its components via GC/MS and investigated possible targets of the major components of the plant using qPCR and docking studies. Cytotoxicity tests showed dose dependent cell killing activity and flow cytometry assays exposed apoptotic effects of Santo. The essential oil also remarkably decreased migration rate of A549 cells, therefore we evaluated the expression levels of epithelial to mesenchymal transition related genes E-cadherin and Vimentin ratio, ZEBI and SNAIL and another motility related gene Ezrin. Santo did not change the expression of EMT related genes but decreased Ezrin levels. According to the results of the GS/MS analysis, Artemisia ketone and Camphor were identified as major molecules of the extract. Docking analysis also revealed that artemisia ketone, the major component of the Santo extract, potentially showed strong binding to the active site of ezrin protein and both artemisia ketone and camphor had ability to bind DNA. The results of the present study indicate that Santo and its components artemisia ketone and camphor are promising anticancer agents, and their potential in targeting DNA and oncogenic proteins in the lung cancer cells seems worth to focus on this plant in cancer related drug discovery science.
\end{abstract}

Keywords: essential oil, lung cancer, antitumor agents, ezrin, santolina chameacyparissus, molecular docking, artemisia ketone, camphor

\section{Introduction}

Aromatic plants have been used since ancient times for their medicinal properties. These properties can be partially or wholly related to their volatile oil fractions which can be also referred as essential oil (Merle et al., 2004). Various essential oils have been used to treat illnesses at different periods in the history can now be reached at the market and subject to regulation in most countries (Baser and Buchbauer, 2010). The diverse therapeutic potentials of essential oils have attracted the attention of many researchers to investigate their anticancer activity because of the limitations and adverse effects of common antitumor agents.

Santolina chameacyparissus also known as Cotton Lavender or Gray Santolina, is an evergreen plant that belongs to the Asteraceae family which has grayish leaves and yellow flowers. It is an aromatic plant, mostly found in Mediterranean region and traditionally used for pain release of premenstrual syndrome, treatment for infections and infestations and digestive disorders due to its anti-inflammatory effects (Mete, 2019). Studies in the literature from Tunisia, Algeria and India also support antimicrobic and antiparasitic activities of the plant (Suresh et al., 1997; Boudoukha et al., 2016, Bel Hadj Salah-Fatnassi et al., 2017) and recently, possible cytotoxic effects of Santo's on cancer cells have also been shown (Elsharkawy, 2014). Even though the components of the essential oils are different between these studies, oxygenated monoterpenes and sesquiterpenes consist most of the essential oil derived from Santo. Among monoterpenes, limonene, peryllil alcohol have been shown to prevent breast, liver, lung, and other cancers (Crowell, 1999), and p-cymene and thymoquinone contribute to autophagic cell death in ovarian, breast and colon adenocarcinoma cells (Ashrafizadeh et al., 
2019). There are other individual studies focusing on the effects of other components of essential oils derived from various herbals such as $\beta$-pinnen, myrcene, artemisia but there still little is known about the effects of Santo's anti-tumoral activity and which of its compounds might have which of the effect remains uncertain.

In this study, to explore anticancer effects of Santolina chameacyparissus, we derived essential oil from the plant, from southern part (Osmaniye city) of Turkey and identified its components via GS/MS. We used two non-small cell lung cancer (NSCLC) cell line; one was a patient derived and the other one was a commercially available, and evaluated the antitumoral activity of Santolina chamaecyparissus on these cells. Via docking studies, we speculate Ezrin is a possible target of Artemisia ketone which came forward as the major component of the plant.

\section{Materials and methods}

\subsection{Isolation of the essential oil}

On April 2018, leaves were collected from the $S$. chamaecyparissus plant and tree of $C$. aurantium grown in the Karacaoglan campus of Osmaniye Korkut Ata University, Osmaniye, which is $20 \mathrm{~km}$ away from the East Mediterranean Sea (37 $02^{\prime} 303^{\prime \prime N}$; 36 $\left.13^{\circ} 0.91^{\prime \prime E}\right)$ and $150 \mathrm{~m}$ above sea level. The plant samples were diagnosed by Dr. Fuat BOZOK with the Flora of Turkey and the East Aegean Islands (Davis, 1982). The shade-dried samples were powdered in a Waring blender and hydrodistillated for three hours using a Clevenger according to the method recommended in the current European Pharmacopoeia to obtain essential oils (European Pharmacopoeia, 2008). The essential oils were dried over anhydrous sodium sulphate and stored in an amber vial in the dark at $4^{\circ} \mathrm{C}$ for further use.

\subsection{Gas chromatography-mass spectrophotometry analysis} The components and the quality of the extracted essential oil was investigated using gas chromatography (GC, Agilent Technologies $6890 \mathrm{~N}$ Network system) with flame ionization detection (FID) detector GC/FID and gas chromatography combined with a mass selective detector GC/MS (Ulukanli, et al., 2015). Retention indices (RI) calculations were also confirmed with the results obtained from alkanes (C8-C32). Further, RIs of the constituents were compared with the authentic substances. Mass spectra data of the tested complex were crosschecked with the earlier data in the GC/MS databases of the Wiley 2001 library data (NIST 02 version 2.62) and the published references (Adams, 2009).

\subsection{Establishment of primary cell line (SA7) and cell culture conditions}

Pathologist approved lung squamous cell carcinoma tumor specimens was derived from a 61-year-old male patient who was operated at the Çukurova University Medical Center and given consent to join the research. Ethical approval was obtained from the Local Ethical Board (Number: 2018-73). Small fragments of the tumor tissue $\left(1 \mathrm{~mm}^{3}\right)$ washed twice in
PBS and re-suspended in cell culture medium (RPMI-1640 supplemented with 10\% fetal bovine serum (FBS) and 1\%, 200 $\mathrm{IU} / \mathrm{ml}$ penicillin-streptomycin) then plated in flasks. Cellculture medium was replaced every three to five days and the cells were cultivated using trypsin to eliminate fibroblasts before starting experiments. A549 cells were provided from Gaziantep University and maintained with the same conditions with SA7 primary cells. Both A549 cells and SA7 cells were cultured under standard conditions at $37^{\circ} \mathrm{C}$ with $5 \% \mathrm{CO}_{2}$.

\section{4. siRNA transfection, western blot, and antibodies}

Ezrin siRNA (Ambion Life \#s1496) and ON-TARGET plus non-targeting control siRNA (Dharmacon, \#D001818-02) were transfected as previously described (Saygideger-Kont et al., 2016) using Lipofectamine 2000. For western blot, cells were lysed with RIPA buffer $(50 \mathrm{mM}$ Tris $\mathrm{HCl} \mathrm{pH} \mathrm{7.4,}$ $1 \%$ Nonidet p- $40,0.5 \%$ Na-deoxycholate, $0.1 \%$ SDS, $150 \mathrm{mM}$ $\mathrm{NaCl}, 2 \mathrm{mM}$ EDTA, $50 \mathrm{mM} \mathrm{NaF}$ ) supplemented with protease and phosphatase inhibitors and DNAse. For protein quantification, bicinchoninic acid assay was performed and samples were boiled in SDS-PAGE sample buffer as previously described (Saygideger-Kont et al., 2016). Antibodies were as follows: Ezrin (E8897) from SigmaAldrich, Actin (C-11) from Cell Signaling, Alexa-Fluor mouse (A21235) secondary and DAPI (D1306) from Thermo Fisher.

\subsection{Immunofluorescence (IF) and microscopy}

IF staining of A549 cells to confirm Ezrin expression was performed as previously described (Saygideger-Kont et al., 2016). Basically, cells were seeded onto collagen coated coverslips in 12-well plates and fixed with $3.7 \%$ paraformaldehyde in PBS, permeabilized and blocked with $1 \%$ BSA, $10 \%$ goat serum and $0.5 \%$ Triton X-100 in PBS before incubation with primary and secondary antibodies and DAPI in the dark. Nikon Eclipse Ti-S microscope with Nikon Intensilight C-HGFI illuminator used to detect images.

\subsection{Cell viability}

Santo was tested for its cytotoxic effect against two NSCLC cell line, one is a new primary squamous cell lung cancer cell line SA7 and other one is a well-studied lung adenocarcinoma cell line A549, using (MTT) Thiazolyl Blue Tetrazolium Bromide method as previously described (Saygideger-Kont et al., 2016). Briefly, SA7 cells $\left(1.0 \times 10^{4} / 200 \mathrm{~mL} /\right.$ well $)$ were cultured in a 96 -well plate for overnight at $37^{\circ} \mathrm{C}, 5 \% \mathrm{CO}_{2}$ and $80 \%$ humidity in their respective medium containing $10 \% \mathrm{FBS}$ and $1 \% \mathrm{AB}$. After $24 \mathrm{~h}$ old medium was removed and the cells were incubated with $0-500 \mu \mathrm{g} / \mathrm{mL}$ concentrations of the oils for 24 and $48 \mathrm{~h}$ at $37^{\circ} \mathrm{C}, 5 \% \mathrm{CO}_{2}$. Cells with $0.1 \%$ DMSO (vehicle control) and cisplatin (positive control) were also incubated at the same conditions. After incubations, $20 \mu \mathrm{L}$ of MTT solution ( $5 \mathrm{mg} / \mathrm{mL}$ in PBS buffer) was added and the cells were further incubated at $37^{\circ} \mathrm{C}, 5 \% \mathrm{CO}_{2}$ for $4 \mathrm{~h}$ to metabolize MTT by viable cells. After MTT treatment, the supernatants were carefully removed, $50 \mu \mathrm{L}$ DMSO was added to each well and then absorbance was measured at $630 \mathrm{~nm}$ subtracted from optical density at $570 \mathrm{~nm}$ in a multi-well plate reader. 


\subsection{Flow cytometry}

To determine the apoptotic effects of the essential oils on the cells in vitro, Annexin V staining was performed according to the protocol of BD Pharmingen ${ }^{\mathrm{TM}}$ FITC Annexin V Apoptosis Detection Kit. For quantitative analysis, $200 \mu \mathrm{M}$ and $400 \mu \mathrm{M}$ concentrations of essential oil were tested on A549 cells. Cell suspension $\left(1.0 \times 10^{7}\right.$ cells $\left./ \mathrm{mL}\right)$ in serum-free medium was incubated with the respective compound in 6-well plates in the $\mathrm{CO}_{2}$ incubator. At the $24^{\text {th }}$ and $48^{\text {th }}$ hour, the cells were harvested and incubated with FITC-Annexin V and PI. The fluorescence emission of FITC-Annexin-V-stained cells was measured at $633 \mathrm{~nm}$ (Red laser) in a flow cytometer (Beckman Coulter/CytoFLEX, United States). Dots represent cells as follows: lower left quadrant, normal cells (FITC-/PI-); lower right quadrant, early apoptotic cells (FITC+/PI-); upper left quadrant, necrotic cells (FITC-/PI + ); upper right quadrant, late apoptotic cells (FITC+/PI + ).

\subsection{Scratch assay}

A549 cells were plated in $6 \mathrm{~cm}$ plates in regular growth medium containing $10 \%$ FBS. After $24 \mathrm{~h}$, a straight-line scratch was made on cell layers using a sterile $1 \mathrm{~mL}$ disposable pipette tip and washed with PBS. Then, the cells treated either with the essential oil $(200 \mu \mathrm{g} / \mathrm{mL})$ or with PBS in the growth media. Images of cell migration were taken using inverted microscope at $0 \mathrm{~h}$ and $24 \mathrm{~h}$ after the scratch. Gap lengths from various points of the scratch were measured using Image J.

\subsection{Quantitative Polymerase chain reaction (qPCR) and primers}

Total RNA was extracted from A549 cells using RNA isolation kit (Macherey-Nagel, Germany) and reverse transcribed using High-Capacity cDNA Reverse Transcription kit (ThermoFisher Sci.) according to their protocols. qPCR was performed on Light Cycler 480 Instrument (Roche) in 96 wellplate in triple form for each condition using SYBR green mix (Ampliqoon). 18S rRNA was used as internal control gene and fold differences were calculated using $2^{-(\Delta \Delta C T)}$ method which $\Delta \Delta \mathrm{CT}$ symbolize (Normalized control sample CT)(Normalized treated sample CT) (Table 1).

Table 1. Primers used in the experiments

\begin{tabular}{|c|c|c|}
\hline Gene name & & Primer sequence \\
\hline \multirow{2}{*}{ 18S rRNA } & $\mathrm{F}$ & $5^{\prime}$-cttagagggacaagtggcg-3' \\
\hline & $\mathrm{R}$ & $5^{\prime}$-acgctgagccagtcagtgta-3' \\
\hline \multirow{2}{*}{ E-Cadherin } & $\mathrm{F}$ & 5 '-gtcattgagcetggcaatttag-3 \\
\hline & $\mathrm{R}$ & 5 '-gttgagactcctccattccttc-3' \\
\hline \multirow{2}{*}{ Vimentin } & $\mathrm{F}$ & 5'-cagctttcaagtgcctttctg-3 \\
\hline & $\mathrm{R}$ & 5'-cttgtaggagtgtcggttgtt-3 \\
\hline \multirow{2}{*}{ Ezrin } & $\mathrm{F}$ & 5'-catcactgaggcagagaagaac-3' \\
\hline & $\mathrm{R}$ & 5'-tgtcattgtgggtcctcttattc-3' \\
\hline \multirow{2}{*}{ SNAIL } & $\mathrm{F}$ & 5 '-gcgatgcccagtctagaaa-3 \\
\hline & $\mathrm{R}$ & 5'-ggtaatgtgtgggtccgaata-3 \\
\hline \multirow{2}{*}{ ZEB1 } & $\mathrm{F}$ & $5^{\prime}$-cttctcacactctgggtcttattc-3' \\
\hline & $\mathrm{R}$ & $5^{\prime}$-cgttcttccgettctctcttac-3' \\
\hline
\end{tabular}

2.10. Molecular docking studies

In this process, Discovery Studio (DS) 2019 (Dassault
Systèmes, 2019) was used to exert molecular docking for understanding interactions between 3,3,6-Trimethylhepta-1,5dien-4-one (Artemisia ketone, AK) and Ezrin. Molecular docking includes three steps. First step, the small compound as ligand and human ezrin model structure were prepared using Gaussian 09 (Frisch et al., 2009) and DS 2019 (Phang et al., 2016) software for molecular docking calculations. The ligand, artemisia ketone was drawn and minimized at DFT/B3LY/631G* level by using G09. The protein crystal structure of ezrin (PDB code: 4RM9) (Phang, et al., 2016) was taken from the Protein Data Bank. The target protein subsequently optimized using CHARMm forcefield and the adopted-basis NewtonRaphson (ABNR) method (Chattaraj et al., 2011) available in the DS 2019 protocol until the root mean square deviation (RMSD) gradient was $<0.05 \mathrm{kcal} / \mathrm{mol} \AA^{2}$. Second step, the active sites were determined by using define and edit binding site subprotocol of DS software. Lastly, Dock Ligands (CDOCKER) was applied using the default settings. The best pose of the related compound was defined based on the docking score, binding energy and root mean square deviation (RMSD) values.

\subsection{Statistical analysis}

Three replicates for each experiment were performed and values were expressed as the mean and standard deviation. Data were subjected to Prism (v. 8.2) for column analysis, dose-response analysis and for graphics. $\mathrm{P}<0.05$ was counted as significant when indicated.

\section{Results}

3.1. Characterization of the essential oil derived from Santo The oil extracted from $S$. chamaecyparissus by hydro distillation had a pale-yellow color and fragrant pleasant odor. The components, percentages, and retention index of the constituent of the essential oil of Santo is shown in Table 2. Artemisia ketone (33.36\%), and camphor (20.86\%) were found to be the major compounds of the essential oil. The other increased components were determined as alpha-bisabolol (6.65\%), $\quad \beta$-Phellandrene (5.61\%), camphene (4.63\%), sabinene $(2.12 \%), \beta$-pinene $(1.77 \%)$, myrcene $(2.13 \%)$, santolina triene $(1.4 \%)$, and endo-borneol $(2.02 \%)$.

Table 2. Chemical composition of the essential oil from Santolina chamaecyparissus assessed by GC-MS

\begin{tabular}{|l|l|}
\hline Name & \% Area \\
\hline Santolina triene & 1.488 \\
\hline Camphene & 4.639 \\
\hline Sabinene & 2.123 \\
\hline beta-Pinene & 1.772 \\
\hline Myrcene & 2.129 \\
乃-Thujene/beta phellandrene & 5.611 \\
\hline Artemisia ketone & 33.360 \\
\hline Artemisia alcohol & 1.930 \\
\hline Camphor & 20.864 \\
alpha-bisabolol & 6.658 \\
\hline endo-Borneol & 2.023
\end{tabular}


The components of the local essential oil were different from previously published Santo oils (Bel Hadj Salah-Fatnassi et al., 2017; Suresh et al., 1997; Ortiz de Elguea-Culebras et al., 2018; Djeddi et al., 2012) that major component was Artemisia ketone (AK) in the present study. AK is an enone and was found effective in malarial and other parasitic diseases (Radulovic et al., 2013). The plant part and harvesting period usually effect the composition of the corresponding essential oil. However, the quality of an essential oil also depends on several factors which must be taken into consideration such as plant age, vegetation cycle, geographic situation, mode of extraction (Lota et al., 1999; Ferhat et al., 2006) and methods of analysis (Mondello et al., 1995; Boussaada and Chemli, 2007). The differences between the results of this study and previous reports may be attributed to these variables.

\subsection{Santo had cytotoxic effect on lung cancer cells inducing apoptosis}

In cell viability assay we tested different concentrations ( 0 to $1000 \mu \mathrm{g} / \mathrm{mL}$ ) of Santo on lung cancer cells A549 and SA7 for $24 \mathrm{~h}$ and $48 \mathrm{~h}$. Compound had cytotoxic effect on the cells and IC50 values at $24^{\text {th }}$ hour was calculated between 92 to $100 \mu \mathrm{g} / \mathrm{mL}$ for SA7 and 200 to $240 \mu \mathrm{g} / \mathrm{mL}$ for A549 in replicated experiments (Fig. 1). At the $48^{\text {th }}$ hour, IC50 values did not differ with $24 \mathrm{~h}$.

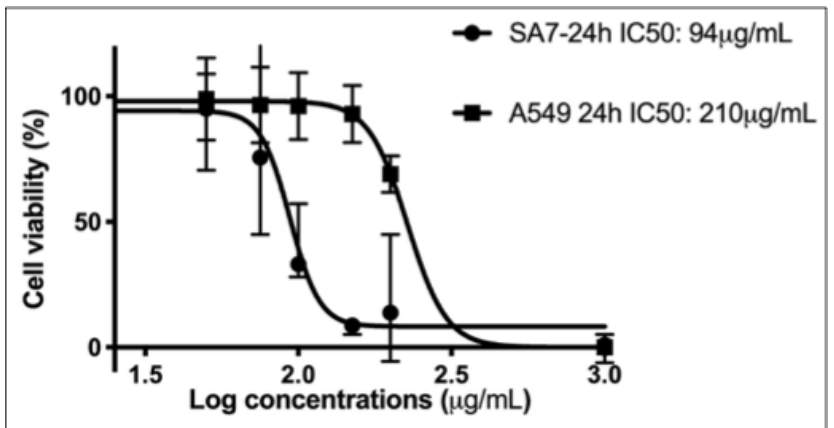

Fig. 1. Cell viability assay. Evaluation of the cytotoxic effect of Santo on SA7 and A549 cells was performed via MTT test with increasing concentrations of Santo ( 0 to $1000 \mu \mathrm{g} / \mathrm{mL})$ for 24 hours. Complex had cytotoxic effects on both cells and IC50 values were calculated using Prism V8

We further evaluated the induction of apoptosis in A549 cells for $24 \mathrm{~h}$ and $48 \mathrm{~h}$. We treated cells with $200 \mu \mathrm{g} / \mathrm{mL}$ and $400 \mu \mathrm{g} / \mathrm{mL}$ concentrations of essential oils and used FITCAnnexin V/PI flow cytometry assay to analyze apoptotic cell ratio. The percentage of apoptosis was found to be higher in the increased dosages and prolonged treatments (Figs. 2A and 2B) and we have concluded that compatible with the cytotoxicity experiments, the essential oil had dose-dependent cytotoxic effects. In addition, the results revealed that Santo had its cytotoxic effect in the apoptotic way. Different studies evaluated Santo extract on cancer cell lines and found different results ranging between high cytotoxicity (has triterpene activity) (Elsharkawy and Aljohar, 2016), to low cytotoxicity against A549 cells (Elsharkawy, 2014). The letter, the extract consisted mainly of oxygenated monoterpene compounds rich in Curcumin, Thujol, limonene oxide, Bornyl, Eucalyptol, alpha-bisabolene epoxide, Carveol, caryophllene oxide and Camphor while in our study main component of Santo was artemisia ketone and camphor which might explain the differences between the results.
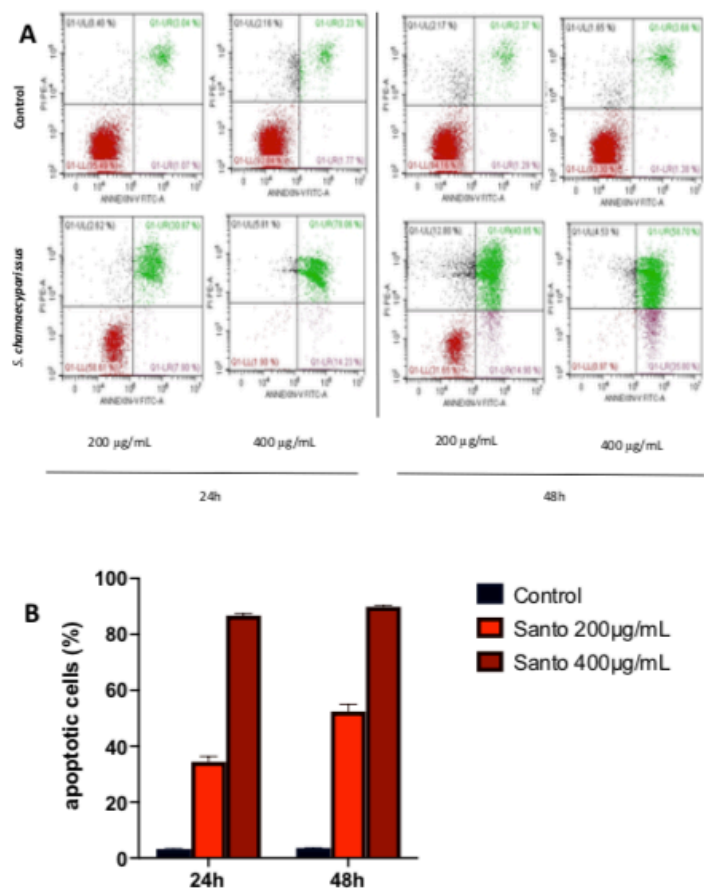

Fig. 2. Flow cytometry analysis of Santo treated A549 cells. Cells were treated with 200 and $400 \mu \mathrm{g} / \mathrm{mL}$ Santo and equal amounts of DMSO as control. Flow cytometry was performed at the $24^{\text {th }}$ and $48^{\text {th }}$ hours of the treatment. In each square image of flow cytometry, upper (late apoptotic cells/green) and lower (early apoptotic cells/purple) right panels show the apoptotic cells of the population (A). Total apoptotic cell rates are given with the bar graph (B)

\subsection{Santo suppressed cell motility in A549 cells}

We investigated the role of Santo, on the motility of A549 cells via scratch assay. The measurements showed a decreased gap closure on with Santo treatment at the end of the $24^{\text {th }}$ hour, comparing to the control cells (Fig. 3A). The percentage of the migrations are shown in Fig. $3 \mathrm{~B}$ and were significantly different between the two groups $(p<0.0001)$. The results suggested that, suppressing cell motility in A549 cells, Santo also had another anti-tumoral effect in lung cancer cells.
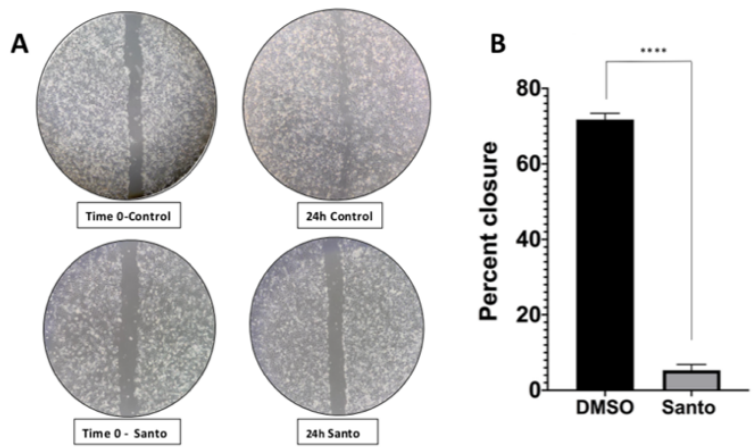

Fig. 3. Effects of Santo on A549 cell migration. Representative images from the scratch assay at time 0 , and $24 \mathrm{~h}$ in the presence of $200 \mu \mathrm{g} / \mathrm{mL}$ Santo (A). The migratory level (\%) of A549 cells were quantified by the gap closure and analyzed via Prism $(* * * * \mathrm{p}<0.001)$ (B) 


\subsection{Santo did not change E-Cadherin / Vimentin mRNA ratio but suppressed Ezrin expression}

To evaluate the underlying mechanisms of Santo's inhibiting cell motility, we evaluated mRNA expression of Epithelial to Mesenchymal Transition (EMT) related genes E-Cadherin, Vimentin, Snail and Zeb1, and additionally Ezrin which codes a cell membrane-cell skeleton connected protein and takes place in cell motility in cancer cells including A549 and claimed to control TGF- $\beta 1$ induced EMT in these cells (Chen MJ et al., 2014). The qPCR results regarding with EMT related genes were non-specific in repeated experiments and $E$ Cadherin / Vimentin ratio did not change after Santo treatment in A549 cells which did not explain the motility suppression after the essential oil treatment (Figs. 4A and 4B). On the other hand, Ezrin expression was significantly down regulated $(p=0.04)$ with Santo treatment which might be the responsible for the inhibition of cell motility in A549 cells (Fig. 4A).

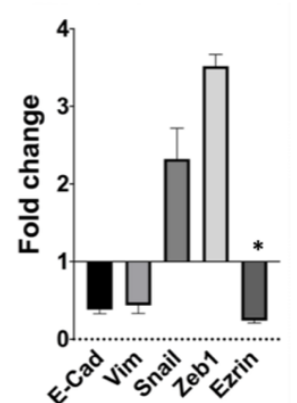

B

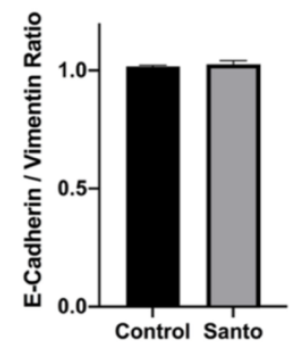

Fig. 4. qPCR analysis of Ezrin and EMT related gene expression. ECadherin, Vimentin, Snail and Zeb1 and additionally Ezrin primers used for qPCR analysis. 18S used as internal control. The mRNA expression of EMT related genes were non relevant that both epithelial marker E-Cadherin and mesenchymal marker Vimentin down regulated after Santo treatment while Snail and Zeb1 expressions were increased. Interestingly, Santo significantly suppressed Ezrin mRNA expression $(\mathrm{p}=0.04)$ (A). Ecadherin/Vimentin ratio did not differ between Santo treated or DMSO treated A549 cells (B)

\subsection{A549 cells expressed ezrin protein and knockdown of Ezrin suppressed cell motility}

After analyzing qPCR results, we decided to knock-down Ezrin in A549 cells to see if the motility effect would be like Santo treated cells. Before knock-down experiments, we evaluated ezrin expression in regularly growing A549 cells with immunofluorescent staining and showed that the cells expressed considerable amount of ezrin especially located in and behind the cell membrane (Fig. 5A). We then knockdowned Ezrin via siRNA technique and performed scratch assay in both Ezrin siRNA and scrambled RNA treated cells. The results revealed that Ezrin down regulation suppressed cell motility in A549 cells alike with Santo treatment (Figs. 5B and 5C). We used western blot to confirm Ezrin knock down (Fig. 5D).

\subsection{Docking Studies showed potential strong arthemisia ketone- Ezrin binding}

In the section 3.1, we have demonstrated that the two major component of Santo used in this research were Artemisia Ketone (AK) and Camphor. Since Santo consisted of multiple compounds, we focused on $\mathrm{AK}$ and camphor to speculate their potential anti-tumor activities and designed docking studies to evaluate the interaction between these two complexes and Ezrin, and DNA.

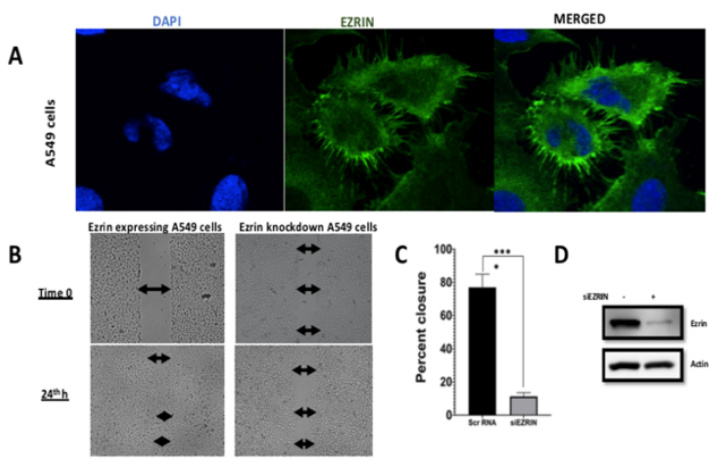

Fig. 5. Ezrin knockdown in A549 cells. We first evaluated Ezrin expression and localization in A549 cells via immunofluorescent staining. A549 cells expressed significant amount of Ezrin and localized in and around the cell membrane as well as cytoplasm (A). After Ezrin knockdown with siRNA, we performed scratch assay (B), and as a result Ezrin knockdown significantly suppressed A549 cell motility $(\mathrm{p}<0.001)$ multiple gap measurements are made using image $\mathrm{J}$ and percent closure is shown in the bar graph (C). Confirmation of Ezrin knockdown via western blot is given (D)

\section{Discussion}

Among these docking evaluation, AK-Ezrin complex had the strongest interaction on one hydrogen bond at Thr567 (2.798 $\AA)$ and had eight hydrophobic interactions with Met558 (4.954

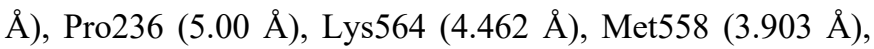
Arg562 (4.897 $\AA)$ and His554 (4.510, 4.828, $4.526 \AA)$, respectively (Fig. 6). The hydrogen bond at Thr567 might inhibit the activity of Ezrin protein because ezrin is known to change its structure from closed to open form to complete its job in the motility and invasiveness of the cancer cells (Antelmi et al., 2013). The detailed information about the mentioned complex can be seen in Supp. Table 3. The results of the docking calculations between $\mathrm{AK}$ and ezrin, comprising of binding energy, docking score and RMSD values are given in Table 3. Specifically, binding energy of any compound shows how the ligand interaction with the target. In this case, the compound, having a low binding energy value to Ezrin ($11.413 \mathrm{kcal} / \mathrm{mol}$ ) supports a strong binding potential. AK, as mentioned before, is a compound that is effective to inhibit malaria (Radulovic et al., 2013) and a recent research suggest that anti-malarial compounds had ability to bind Ezrin in surface plasmon resonance (SPR) and immunoprecipitation and immunoblotting experiments (Celik et al., 2015). Besides, some of these compounds inhibited cell migration and pulmonary metastasis of osteosarcoma cells in-vitro as well as embryonic development in zebrafish assays in-vivo (Celik et al., 2015). This literature, combining with the findings of this research, support the idea of AK's being a potential ezrin inhibitor in Santo extract. 
Table 3. Binding Energy, Docking score and RMSD values of Artemisia ketone and Ezrin

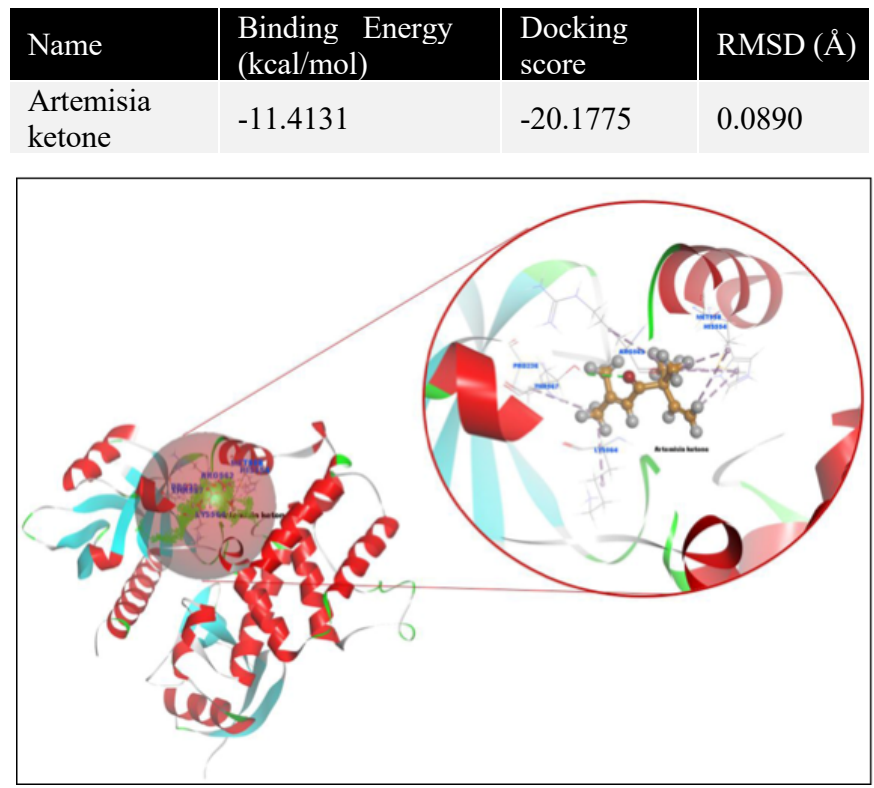

Fig. 6. Top scoring Ezrin along with the crystal structure for compound, Artemisia ketone (orange carbons) shows one H-bonding of the $\mathrm{O}$ atom of ketone group to Thr567 (2.798 $\AA$ ) and eight hydrophobic interactions of the related compound at Met558 (4.954

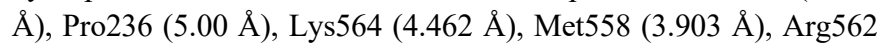
$(4.897 \AA)$ and His554 (4.510, 4.828, $4.526 \AA)$, respectively

We also studied DNA docking of AK and Camphor which the results indicate weaker binding comparing to AK-Ezrin binding (Fig. 7). Since DNA is a complex biomolecule to be affected from every biochemical change occurring in the cells, the interaction of small compounds with DNA might generate significant effects. The DNA bindings of these two molecules provide that AK-DNA interaction is more stable than Camphor-DNA interaction, based on their calculation of binding energies. In the meantime, these interactions are revealed that the related compounds are intercalating agents on DNA. The results regarding DNA are in Table 4.

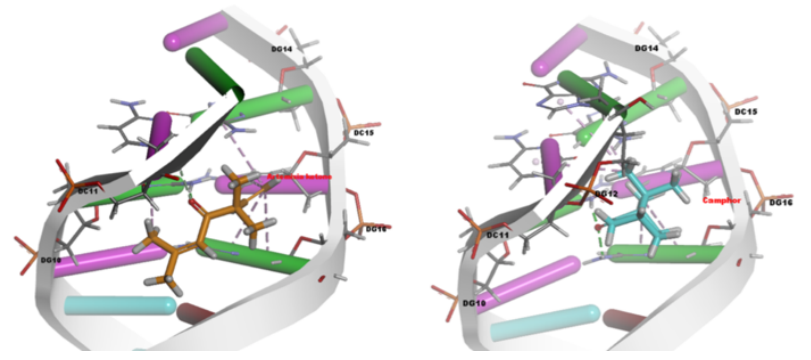

Fig. 7. We also studied DNA docking of AK and Camphor which the results indicate weaker binding comparing to AK-Ezrin binding

Table 4. Binding Energy, Docking score and RMSD values of Artemisia ketone and Camphor against DNA

\begin{tabular}{l|l|l|l|} 
Name & $\begin{array}{l}\text { Binding Energy } \\
(\mathrm{kcal} / \mathrm{mol})\end{array}$ & $\begin{array}{l}\text { Docking } \\
\text { score }\end{array}$ & $\begin{array}{l}\text { RMS } \\
\mathrm{D}(\AA)\end{array}$ \\
\hline $\begin{array}{l}\text { Artemisia } \\
\text { ketone-DNA }\end{array}$ & -5.480 & -9.1629 & 0.0067 \\
$\begin{array}{l}\text { Camphor- } \\
\text { DNA }\end{array}$ & -5.410 & -34.6270 & 0.0064
\end{tabular}

In this research, the essential oil extracted from Santolina chamaecyparissus, wildly growing around southern part of Turkey, was found to show in vitro anti-cancer activity on A549 cells. The extract induced apoptosis, inhibited cell motility and downregulated Ezrin expression which is a protein that is involved in cell motility and other oncogenic pathways. The major component of the oil Artemisia ketone showed potential strong binding to ezrin protein in the docking studies as potential inhibitor candidate of the protein. Moreover, both major components of Santo are shown to interact with DNA, theoretically. These findings obviously need further investigation to understand the interaction between the Santolina extract and oncogenic proteins such as ezrin in cancer cells as well as in-vivo experiments.

\section{Conflict of interest}

All authors declare no support, financial or otherwise, from any organization for the submitted work.

\section{Acknowledgments}

We would like to thank Dr. Fuat Bozok for obtaining and diagnosing the plant. This study was partially supported by Turkish Thoracic Society Grant Y-1732018 and Cukurova University Scientific Research Support Grant TAY-201910261. We would also like to thank Cukurova University Central Research Laboratories (CUMERLAB) for providing a Lab space for the authors.

\section{References}

1. Adams, R.P., 2009. Identification of essential oils components by Gas Cromatography/Mass Spectroscopy. Allured Publishing Co. Carol Stream Illinois.

2. Antelmi, E., Cardone, R.A., Greco, M.R., Rubino, R., Di Sole, F., Martino, N.A., Casavola, V., Carcangiu, M., Moro, L., Reshkin, S.J., 2013. $\beta 1$ integrin binding phosphorylates ezrin at T567 to activate a lipid raft signalsome driving invadopodia activity and invasion. PLoS One. 8(9), e75113.

3. Ashrafizadeh, M., Ahmadi, Z., Mohammadinejad, R., Kaviyani, N., Tavakol, S., 2019. Monoterpenes modulating autophagy: A review study. Basic Clin. Pharmacol. Toxicol. 126, 9-20.

4. Baser, K. H. C., Buchbauer. G., 2010. Handbook of Essential Oils: Science, Technology and Applications. CRC Press, Boca Raton, London, New York. ISBN 978-1-4200-6315-8.

5. Bel Hadj Salah-Fatnassi, K., Hassayoun, F., Cheraif, I., Khan, S., Jannet, H.B., Hammami, M., Aouni, M., Harzallah-Skhiri, F., 2017. Chemical composition, antibacterial and antifungal activities of flowerhead and root essential oils of Santolina chamaecyparissus L., growing wild in Tunisia. Saudi J. Biol. Sci. 24(4), 875-882.

6. Boudoukha, C., Bouriche, H., Ortega, E., Senator, A., 2016. Immunomodulatory effects of Santolina chamaecyparissus leaf extracts on human neutrophil functions. Pharmaceutical Biology. 54(4), 667-673.

7. Boussaada, O., Chemli, R., 2007. Seasonal variation of essential oil composition of Citrus Aurantium L. J. Essent. Oil-Bear. Plants, 10 (2), 109-120.

8. Çelik, H., Hong, S.H., Colón-López, D.D., Han, J., Kont, Y.S., Minas, T.Z., Swift, M., Paige, M., 2015. Identification of novel ezrin inhibitors targeting metastatic osteosarcoma by screening open access Malaria Box. Mol. Cancer Ther. 14(11), 2497-2507. 
9. Chattaraj, PK, Giri S, Duley S., 2011. Perennial review: Update 2 of Chem Rev 2006. Chem Rev. 11, 43-75.

10. Chen, M.J., Gao, X.J., Xu, L.N., Liu, T.F., Liu. X.H., Liu, L.X., 2014. Ezrin is required for epithelial-mesenchymal transition induced by TGF- $\beta 1$ in A549 cells. Int. J. Oncol. 45(4), 1515-1522.

11. Crowell, P.L. 1999. Prevention and therapy of cancer by dietary monoterpenes. J. Nutr. 129(3), 775-778.

12. Dassault Systèmes BIOVIA, Discovery Studio Modeling Environment, Release 2019, San Diego: Dassault Systèmes, 2016.

13. Davis, P.H., 1982. Flora of Turkey and the East Aegean Islands. Vol 5, p. 252. Edinburgh Univ. Press.

14. Djeddi, S., Djebile, K., Hadjbourega, G., Achour, Z., Argyropoulou, C., Skaltsa, H., 2012. In vitro antimicrobial properties and chemical cpmposition of santolina chamaecyparissus essential oil from Algeria. Nat. Prod. Commun.7(7), 937-940.

15. Elsharkawy, E., Aljohar, H., 2016. Anticancer screening of medicinal plants growing in the Northern region of Saudi Arabia. Natl. J. Physiol. Pharm. Pharmacol. 6, 241-246.

16. Elsharkawy, E.R, 2014. Antitcancer effect and Seasonal variation in oil constituents of Santolina chamaecyparissus. Chem. Mater. 6(3), 85-91.

17. European Pharmacopoeia 6.0., 2008. Determination of essential oils in herbal drugs, 2.8.12, 251-252.

18. Ferhat, M.A., Meklati, B.Y., Smadja, J., Chemat, F., 2006. An improved microwave clevenger apparatus for distillation of essential oils from orange peel. J. Chromato. A. 1112 (1-2), 121126.

19. Frisch, M.J., Trucks, G.W., Schlegel, H.B., 2009. Gaussian09, RevisionE.01, Gaussian, Inc., Wallingford, CT, USA.

20. Lota, M.L., de Rocca Serra, D., Tomi, F., Bessiere J-M. and Casanova, J., 1999. Chemical composition of peel and leaf essential oils of Citrus medica L. and C. limonimedica lush. Flavour Fragr. J. 14, 161.

21. Merle, H., Morón, M., Blázquez, A.M., Boira, H., 2004. Taxonomical contribution of essential oils in mandarins cultivars. Biochem. Syst. Ecol. 32, 491-497.
22. Mete, O., Kabalcı şifalı bitkiler ansiklopedisi. ISBN: 9759971469. Release date 06.04.2019. $1^{\text {st }}$ edition. p.351.

23. Mondello, L., Dugo, P. and Bartle, K.D., Dugo, G. and Cotroneo, A. (1995). Automated HPLC HRGC: A Powerful Method for Essential Oils Analisys. Part V. Identification of Terpene Hydrocarbons of Bergamot, Lemon, Mandarin, Sweet Orange, Bitter Orange, Grapefruit, Clementine and Mexican Lime Oils by Coupled HPLCHRGC-MS (ITD). Flavour Fragr. J. 10, 33-42.

24. Ortiz de Elguea-Culebras, G., Sánchez-Vioque, R., Berruga, M.I., Herraiz-Peñalver, D., González-Coloma, A., Andrés, M.F., Santana-Méridas, O., 2018. Biocidal Potential and Chemical Composition of Industrial Essential Oils from Hyssopus officinalis, Lavandula $\mathrm{x}$ intermedia var. Super, and Santolina chamaecyparissus. Chem Biodivers. 15(1),

25. Phang, J.M., Harrop, S.J., Duff, A.P., Sokolova, A.V., Crossett, B., Walsh, J.C., Beckham, S.A., Nguyen, C.D., Davies, R.B., Glockner, C., Bromley, E.H., Wilk, K.E., Curmi, P.M.G., 2016. Crystal structure of human ezrin in space group C2221. Biochem. J. 473, 2763-2782.

26. Radulović, N.S., Randjelović, P.J., Stojanović, N.M., Blagojević, P.D., Stojanović-Radić, Z.Z., Ilić, I.R., Djordjević, V.B., 2013. Toxic essential oils. Part II: Chemical, toxicological, pharmacological and microbiological profiles of Artemisia annua L. volatiles. Food Chem. Toxicol. 58, 37-49.

27. RHS A-Z encyclopedia of garden plants. United Kingdom: Dorling Kindersley. 2008. p. 1136. ISBN 1405332964.

28. Saygideğer-Kont, Y., Minas, T.Z., Jones, H., Hour, S., Çelik, H., Temel, I., Han, J., Atabey, N., Erkizan, H.V., Toretsky, J.A., Üren, A., 2016. Ezrin enhances EGFR signaling and modulates Erlotinib sensitivity in non-small cell lung cancer cells. Neoplasia. 18(2), 111-120.

29. Suresh, B., Sriram, S., Dhanaraj, S.A., Elango, K., Chinnaswamy, K., 1997. Anticandidal activity of Santolina chamaecyparissus volatile oil. Jour. Ethnopharmacology. 55 (2), 151-159.

30. Ulukanli, Z., Cenet, M., Öztürk, B., Bozok, F., Karabörklü, S., Demirci, S.C., 2015. Chemical characterization, phytotoxic, antimicrobial and insecticidal activities of Vitex agnuscastus' essential oil from East Mediterranean region. J. Essent. Oil Bearing Plants.18(6), 1500- 1507. 